\title{
PRESENTING THE MODEL OF TAX COMPLIANCE: THE ROLE OF SOCIAL- PSYCHOLOGICAL FACTORS
}

\author{
Seyyed Yaser Ebrahimian Jolodar ${ }^{1^{*}}$, \\ Masoud Ahmadi ${ }^{2}$ and Niloofar Imankhan ${ }^{3}$ \\ ${ }^{1}$ Department of Management, Sari Branch, Islamic Azad University, Iran \\ E-mail: syebrahimian@yahoo.com \\ ${ }^{2}$ Department of Management, Sari Branch, Islamic Azad University, Iran \\ E-mail: ahmadi.m72@yahoo.com \\ ${ }^{3}$ Department of Management, Firoozkuh Branch, Islamic Azad University, Iran \\ E-mail: niloofar_im@yahoo.com
}

\begin{abstract}
Today, the concept of tax compliance has become a common phenomenon and attracted the attention of a large number of researchers in order to identify the factors affecting it. Previously, studies of tax compliance have concentrated on the effect of economic variables and less attention is paid to social-psychological factors. So, the purpose of this research is to present the model of tax compliance by considering the social-psychological factors. From the population of 2,900 legal persons of Sari tax administration in Iran who are liable to Value-Added Tax (VAT), 550 legal persons were stratified randomly. For assessing construct validity, we used the SEM method and a confirmatory factor analysis was performed with the help of Analysis of Moment Structures. The findings revealed a significant and positive impact of tax fairness, taxpayers' attitude, trust in authorities and tax morale on tax compliance. Furthermore, the results showed that tax compliance is largely determined by tax morale. Moreover, the results suggest that tax authorities should concentrate on tax fairness for creating favorable attitudes among taxpayers, enhancing trust in authorities and improvement of morale obligation.
\end{abstract}

Keywords: tax compliance, taxpayers' attitude, tax fairness, tax morale

$\underline{\text { ARTICLE INFO }}$

\section{Article History:}

Received: 23 February 2019

Accepted: 17 July 2019

Published: 31 August 2019 


\section{INTRODUCTION}

Tax compliance is of paramount importance for the government to provide public goods and reallocate wealth (Jayawardane \& Low, 2016). For the government to be able to provide public goods and reallocate wealth, there is a need for taxpayers to comply and pay the correct amount of taxes due and on time (Night \& Bananuka, 2018; Musimenta et al., 2017; Nkundabanyanga et al., 2017). Tax revenue sustains economic development and finances both social programmes and infrastructure investment (Ibrahim et al., 2015). Osundina and Olanrewaju (2013) state that taxation is a key player in every society of the world because it is a chance for the government to collect revenue needed for satisfying its pressing obligations. Actually, taxes are a major part through which monetary resources are mobilized by governments for the prosecution of projects and programs. These projects and programs are usually undertaken with the view to providing varied services to the citizenry such as road infrastructure, internal security (Abdul-Razak \& Adafula, 2013), better national health care, educational opportunities, and other essential public services which is expected to press governments to urge taxpayers not to avoid or under-declare their tax obligations (Young et al., 2013).

Despite the significance of taxation and several tax reforms such as tax education and online tax services, non-tax compliance is still a challenge (Nawawi \& Salin, 2018; Nkundabanyanga et al., 2017; Musimenta et al., 2017; Terkper, 2003) and it remains one of the greatest and most important problems in the area of taxation (Bobek et al., 2013). This has led to an emergent interest by many researchers to find out why such tax compliance behaviours exist in business enterprises (Nawawi \& Salin, 2018; Nkundabanyanga et al., 2017; Musimenta et al., 2017; Ndekwa, 2014; Merima et al., 2013; Nkwe, 2013; McCoon, 2011). Nawawi and Salin (2018) note that if there are no proper mechanisms put in place by the tax authorities to prevent tax evasion, there are higher chances that there will be non-tax compliance. Therefore, understanding what drives tax compliance is an important topic for scientific study (Gobena \& Van Dijke, 2015) and has become an area of interest for policymakers, academics, tax practitioners, and the general public in the last two decades (Jimenez \& Iyer, 2016). On the other hand, reducing tax non-compliance is not just a matter of applying higher penalties and/or increasing the probability of detection. The first 
to recognize that the model does not capture all the rationales of tax noncompliance were the authors themselves as they state in their paper: "This is a very simple theory, and it may perhaps be criticized for giving too little attention to nonpecuniary factors in the taxpayer's decision on whether or not to evade taxes" (Horodnic, 2018; Allingham \& Sandmo, 1972). Moreover, tax authorities often show little trust in taxpayers and seem to believe that deterrent actions (economic variables) can solve all problems related to tax (non-)compliance. Therefore, taxation environments in developing countries often feature so-called "cops and robbers" relationships between taxpayers and the tax authority (Kirchler et al., 2008). So, the aim of this paper is to examine the effects of social-psychological factors affecting tax compliance and in return, try to present the tax compliance model. The study comprises of various sections representing a review of the literature methodology, data analysis and findings, discussion and conclusion. At the end, the recommendations for future research is presented.

\section{LITERATURE REVIEW AND HYPOTHESIS DEVELOPMENT}

\section{Tax Compliance}

Tax compliance has been extensively researched and yet, the question of why people pay taxes remains only partially answered. Tax noncompliance continues to represent a core issue for many governments around the world (Horodnic, 2018). Tax compliance is a complex term to define. Jackson and Milliron (1986) defined it as the reporting of all incomes and tax payments to the relevant tax authority (Mas'ud et al., 2014). It can also be defined as an individual's "act of filing tax returns, declaring all income accurately for tax purposes and paying tax liabilities on the due dates as stipulated by the authority or applicable tax laws" (Palil \& Mustapha, 2011). Kirchler (2007) perceived a simpler definition in which tax compliance is defined as the most neutral term to describe taxpayers' willingness to pay their taxes. According to Brown and Mazur (2003), tax compliance is multi-faceted measure and theoretically, it can be defined by considering three distinct types of compliance such as payment compliance, filling compliance, and reporting compliance. 
In recent years, economic development has become important and crucial issue in developing countries. So these communities do their best to increase their investment by reliance on their own revenues (Savitri \& Musfialdy, 2016). In the meantime, according to Alm et al. (2004) tax noncompliance is actually an inevitable fact on the social level (Alasfour et al., 2016) and each year trillions of dollars slip through the tax authorities' fingers as a consequence of tax evasion (Balafoutas et al., 2015). The other researches also have shown that tax evasion is a pervasive problem in many countries. In particular, some developing countries do not collect even half of what they would if taxpayers complied with the written letter of the law (Castro \& Scartascini, 2015). The Tax Justice Network (2011) estimates that, on average, tax evasion rates in 119 developed and developing countries around the world exceed $50 \%$ of their healthcare spending. Also, Schneider (2000) reports that the shadow output equals $39 \%$ of the actual magnitude of reported GDP in developing countries, $23 \%$ in transition countries and $14 \%$ in OECD countries. Schneider and Enste (2000) and Bajada (2003) suggest that the underground economy and the associated tax evasion deepen recessions and increase the volatility of business cycles. So, because of the importance of this topic, the purpose of this paper is to contribute an answer to the question What are the social-psychological factors influencing on tax compliance and presenting the model of tax compliance?

\section{Tax Fairness}

Perceptions of fairness may be especially important in tax compliance decisions. General theories of tax compliance support the idea that perceptions of fairness inluence tax compliance (Almasi et al., 2014; Jimenez \& Iyer, 2016) and it is widely believed by tax administrators and the taxpayers that growing dissatisfaction with the fairness of tax system, is the major cause for increasing tax noncompliance (Chau \& Leung, 2009). A conceptual framework for fairness considerations suggests differentiating three areas of fairness, as in social psychology: (i) procedural justice, (ii) distributive justice and (iii) retributive justice (Kirchler et al., 2008). Related to procedural justice, the components essential for perceived fairness are neutrality of the procedure, trustworthiness of the tax authorities and polite, dignified, and respectful treatment (Murphy, 2003). Perceived procedural justice on the individual level and a culture of interaction are important for building up trust (Job et al., 2007). Empirical studies show that authorities 
who enact procedures in a fair manner gain more positive responses from members of the collective (Van Dijke et al., 2010). Furthermore, Levi and Sacks (2009) find that government effectiveness and procedural justice are key contributors to high tax morale.

Distributive justice concerns the exchange of resources with regard to benefits and costs of the tax system. If the tax burden is perceived to be heavier than that of comparable others, compliance is likely to decrease. Distributive justice is assumed to affect perceived trustworthiness of tax authorities and should therefore entail a higher degree of voluntary compliance (Kirchler et al., 2008). Also, Abdul-Razak and Adafula (2013) proved empirically that the burden of taxes paid affects the attitudes of individuals and this informs how they evaluate the tax system and consequently their compliance decisions Finally, retributive justice refers to the appropriateness of sanctions in case of an offence. Unreasonable, intrusive audits and unfair penalties are said to evoke negative attitudes towards taxes and the responsible authorities (Wenzel \& Thielmann, 2006). In addition, Torgler et al. (2009) proved that perceived unfairness increases the incentive to act against the tax law, as it reduces psychological costs. Consequently, we hypothesized that:

$\mathbf{H}_{1}$ : Tax fairness has a positive effect on taxpayers' attitude.

$\mathbf{H}_{2}$ : Tax fairness has a positive effect on trust in authorities.

$\mathbf{H}_{3}$ : Tax fairness has a positive effect on tax compliance.

\section{Taxpayers' Attitude}

Attitudes are often defined as evaluations in relation to a particular object, person, behavior, etc. (Ajzen, 1991). Onu (2016) believed that they are complex psychological constructs that are theorized to have several components: cognitive components (the beliefs that accompany an attitude), affective components (the emotional response related to an evaluation) and a behavioral component (the behavioral tendencies associated with an attitude). Breckler and Wiggins (1989) argued that affective attitude deals with emotions such as feeling happy, sad or guilt when performing certain behavior while instrumental attitude refers to a more cognitive consideration to which performing a behavior would be advantageous. Also, Solomon et al. (2006) have said that behavioral attitude expresses the individual's 
intention to do activities. A recent study, Loo et al. (2007) reported that attitudes towards tax system positively influenced compliance behavior. They hypothesized that a positive attitude towards the tax system would encourage taxpayers to comply. Thus, it was anticipated that taxpayers with favorable perceptions of the tax system were more likely to have a positive attitude. Chan et al. (2000) reported that Hong Kong taxpayers have a less favorable attitude towards the tax system as a result of a lower level of compliance. Trivedi et al. (2005) also revealed that there is a relationship between attitude and tax compliance. Kirchler et al. (2008) suggested that a taxpayer who has a favorable attitude towards tax evasion is expected to be less compliant and equally a taxpayer with an unfavorable attitude is likely to be more compliant. The study of Jayawardane and Low (2016) reveals that positive taxpayers' attitudes encourage tax compliance.

In addition, taxpayers' attitude to tax evasion is a factor affecting their tax ethics. In other words, as tax evasion becomes abhorrent in a taxpayer's viewpoint, their tax ethics will be improved and in turn, their tax evasion will be reduced (Sameti et al., 2015). Trivedi et al. (2004) found that the attitudes are important for both the power and the trust dimension. On the one hand, favorable attitudes will contribute to trust in authorities and consequently will enhance voluntary tax compliance. Thus, from this discussion, we hypothesized that:

$\mathbf{H}_{4}$ : Taxpayers' attitude has a positive effect on tax morale.

$\mathbf{H}_{5}$ : Taxpayers' attitude has a positive effect on tax compliance.

\section{Trust in Authorities}

Rousseau et al. (1998) defined trust as "a psychological state comprising the intention to accept vulnerability based upon positive expectations of the intentions of another (Jimenez \& Iyer, 2016). Kirchler et al. (2008) also defined trust as "a general opinion of individuals and social groups that the tax authorities are benevolent and work beneficially for the common good. The researchers believed that trust in government can have positive consequences for the regime; one potential positive consequence is increased taxpayer compliance (Jimenez \& Iyer, 2016). Torgler (2007) argued that a taxpayer's relationship with the government, including their trust in government, was an important consideration when 
examining voluntary tax compliance. Findings from prior research on national and international survey data show that trust in tax authorities is positively related to tax compliance (Torgler \& Schneider, 2005). Trust emphasizes the relationship between the taxpayer and tax authority resulting from the trust of the taxpayer in the tax authority's actions. If a taxpayer has high trust in the tax authority, tax compliance is perceived to increase as well (Kastlunger et al., 2013). Fjeldstad (2004) found that trust in the government, as well as perceived procedural fairness, affects compliance of paying service charges in South Africa (Wahl et al., 2010). Hammar et al. (2009) note that tax compliance is fostered by the trustworthiness of policymakers (Kogler et al., 2013). In a recent review of tax compliance studies, Lavoie (2008) emphasized the important role of trust in authorities to foster tax compliance. Similarly, Kogler et al. (2013) showed that voluntary compliance is more influenced by the taxpayer to the government's trust, especially against the tax system. In a research in Ghana, Abdul-Razak and Adafula (2013) proved empirically that taxpayer trust on the government can increase tax compliance.

Furthermore, various studies report that trust in the government and in governmental institutions positively influences tax morale (Torgler \& Schneider, 2005). Torgler (2003) analyzes compliance behavior in transition countries and concludes that trust in the legal system and the government increases tax morale. Frey (2003) argues that tax morale decreases when taxpayers have little trust in authorities and are treated with no respect. Sá et al. (2014) also suggest that trust in others, and individual's identification with Portugal have a significant effect on tax morale. Recently, Leonardo and Martinez-Vazquez (2016) show that trust in administrative government institutions positively influences tax morale. Consequently, we hypothesized that:

$\mathbf{H}_{6}$ : Trust in authorities has a positive effect on tax morale.

$\mathbf{H}_{7}$ : Trust in authorities has a positive effect on tax compliance.

\section{Tax Morale}

Taxpayers' behavior towards a tax system has evoked great attention among many revenue authorities in the world especially in developed countries (Marti et al., 2010). It can be supposed that nobody likes to pay 
taxes. One possibility which enforced people to pay their taxes is the morale obligation, the belief in contributing to society by paying taxes (Torgler, 2004). In fact, taxpayers' concern for social duty or personal responsibility has been shown empirically to shape compliance. Some taxpayers pay taxes because they believe it is the right thing to do, irrespective of sanctions. Individual moral beliefs have been found to be highly significant in tax compliance decisions (Mei Tan \& Braithwaite, 2017). So, a better understanding on individual heterogeneity in tax morale may contribute to the development of alternative mechanisms to reduce tax evasion and to improve tax compliance. Such knowledge is of particular importance because of the negative consequences that tax evasion has on public revenues, and on equity level of the tax system (Kim, 2008).

Tax morale is defined as an intrinsic motivation to pay tax on time (Torgler, 2003), and the intrinsic motivation states paying tax regularly without external force (Aktan, 2006). Besides, it is known as being paid of all tax debts completely. It can be said that tax morale is high in a country, only if all tax debts are paid on time regularly (Yeniçeri, 2004). Many researchers have argued that tax morale, seen as the intrinsic motivation to pay taxes, can help explain the high degree of tax compliance (Feld \& Frey, 2002). Recent research recognizes tax morale as the key to explain the levels of compliance obtained in most countries. Empirical studies found strong evidence of a negative correlation between tax morale and tax evasion and between tax morale and the size of shadow economy (Dell'Anno, 2009). Consequently, we propose that:

$\mathbf{H}_{\mathbf{8}}$ : Tax morale has a positive effect on tax compliance.

\section{RESEARCH MODEL}

Based on the literature, a conceptual model was propounded in this study. This model consists of the relevant variables based on the previous studies. All these key variables were identified from the existing literature and a hypothesized link was established. In this model, based on structural equation modeling (SEM), taxpayers' attitudes, trust in authorities, tax morale and tax compliance were considered as an endogenous variables and tax fairness as an exogenous variable. So, the intention of the development 
of this model is to get an understanding of the social-psychological factors affecting tax compliance. According to the results of previous studies and the models presented none of these researches considered these variables together in an integrated model. Thus, in order to eliminate this gap, we considered the relationship between these structures in an integrated model. Figure 1 shows the research model.

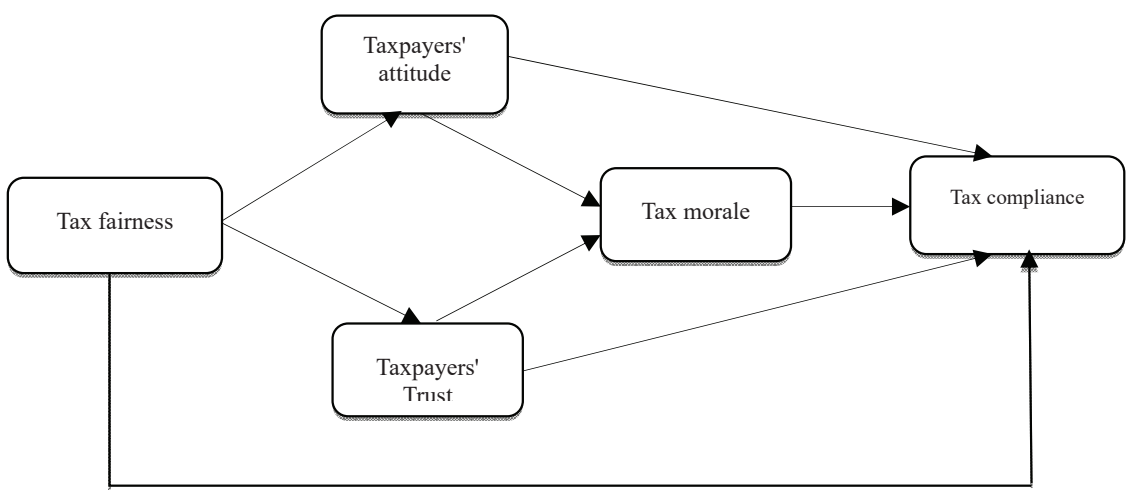

Figure 1: Research Model

\section{METHODOLOGY}

\section{Participants and Procedure}

Regarding the research purpose, this study is an applied research and according to data gathering, it used a descriptive-correlation approach. The study included 2900 legal persons of the Sari tax administration who were liable to value-added tax (VAT). The sample size was 550 which was determined by the Cochran formula for a limited statistical population. Data were collected using individually completed questionnaires and the researchers were present to address probable queries from the respondents. The sampling technique in this study was stratified random sampling. So, we divided the companies into six categories according to their date of liability to taxation. Then by using stratified random sampling, the sample for each category was determined. For assessing construct validity, SEM is better than other statistical methods such as multiple regression analysis (Soleimani et al., 2017). A confirmatory factor analysis (CFA) was performed with the help of the Analysis of Moment Structures (Amos) version 22 to check 
the construct validity of each latent construct of the measurement model (Bagozzi \& Edwards, 1998; Hair et al., 1998). The construct validity was checked through convergent validity and discriminant validity. Convergent validity was tested by evaluating the factor loadings and average variance extracted (AVE). The factor loadings and AVE should be greater than the threshold value, that is 0.50 (Lin \& Ding, 2006). The reliability was evaluated by Cronbach's alpha and the calculated coefficient of (0.875) for overall items which represented a high and desirable internal consistency.

\section{Measures}

We measured tax compliance with the 7-item scale from Wahl et al. (2010). It consisted of three components, i.e. filing compliance, reporting compliance, payment compliance. We measured trust in authorities which consists of two components. Cognition-based trust with the 11-item scale and affect-based trust with the 5-item scale developed by McAllister (1995) and was used in Gobena and Van Dijke (2015) research. We slightly adapted the items to fit the context of trust in the tax authority. Furthermore, for assessing tax fairness, taxpayers' attitude and tax morale, the Persian version of the questionnaire was used. For this, at first, we identified the indicators and components of these construct from the literature and the other researches. Second, by consultation with the supervisor and advisor and the other experts in tax and financial issues, the questions were adopted and modified for the context of the present study with a 5 point Likert scale from (1 strongly disagree to 5 strongly agree) to evaluate the relationship among the constructs. Thus, we measured taxpayers' attitude with the 10item scale, which consisted of three components, i.e., affective attitude, cognitive attitude and behavioral attitude. Also, we measured tax morale with the 6-item scale, which consisted of three components, i.e., morale obligation, tell the truth and contributing to the society. Finally, tax fairness measured with the 16-item scale which consisted of three components, i.e., procedural justice, distributive justice and retributive justice. 


\section{DATA ANALYSIS AND FINDINGS}

\section{Demographic Profile}

The demographic profile of the taxpayers is shown in Table 1 below. The majority of the respondents are male with 297 (54\%) respondents, while the female respondents are 253 , equivalent to $46 \%$. The age group of the respondents shows that the majority of the age group is between the ages $31-40$ years with $40 \%$. On the question of education, the majority of respondents are bachelor degree holders with a total response of 335 representing with $61 \%$ of the total respondents

Table 1: Demographic Details of the Respondents

\begin{tabular}{llcc}
\hline & Variables & Frequency & \%age \\
\hline \multirow{2}{*}{ Gender } & Male & 297 & $0 / 54$ \\
\cline { 2 - 4 } & Female & 253 & $0 / 46$ \\
\hline \multirow{2}{*}{ Age } & $20-30$ years & 84 & $0 / 15$ \\
\cline { 2 - 4 } & $31-40$ years & 223 & $0 / 40$ \\
\cline { 2 - 4 } & $41-50$ years & 174 & $0 / 32$ \\
\cline { 2 - 4 } & 51 years and above & 69 & $0 / 13$ \\
\hline \multirow{2}{*}{ Level of education } & Diploma & 25 & $0 / 045$ \\
\cline { 2 - 4 } & Bachelor & 335 & $0 / 61$ \\
\cline { 2 - 4 } & Master & 187 & $0 / 34$ \\
\cline { 2 - 4 } & Ph.D & 3 & $0 / 005$ \\
\hline
\end{tabular}

\section{Exploratory Factor Analysis}

The exploratory factor analysis (CFA) was conducted to identify the item that is applied to a specific component through the principal component analysis. The Kaiser-Meyer-Oklin (KMO) and the Bartlett's test were used in evaluating the data for exploratory factor analysis. According to Hair et al. (1998) the value of KMO above 0.50 is acceptable. The examination of Bartlett's Test of Sphericity for all constructs showed significant results $(\mathrm{p}<0.05)$. This indicates that the data is good enough to proceed for the exploratory factor analysis. The result of the factor analysis is shown in Table 2. 
Table 2: KMO and Bartlett's Test

\begin{tabular}{|c|c|c|c|}
\hline Constructs & $\begin{array}{l}\text { Kaiser-Meyer-Olkin and } \\
\text { Bartlett's Test of Sphericity }\end{array}$ & Component & AVE \\
\hline \multirow{3}{*}{$\begin{array}{l}\text { Taxpayers' } \\
\text { attitude }\end{array}$} & \multirow{3}{*}{$\begin{array}{c}K M O=0 / 874 \\
\text { Chi-Square }=828 / 86 \\
\text { SIG }=0 / 000\end{array}$} & Affective attitude & \multirow{3}{*}{$74 / 232$} \\
\hline & & Cognitive attitude & \\
\hline & & Behavioral attitude & \\
\hline \multirow{2}{*}{$\begin{array}{l}\text { Trust in } \\
\text { authorities }\end{array}$} & \multirow{2}{*}{$\begin{array}{c}K M O=0 / 723 \\
\text { Chi-Square }=029 / 286 \\
S I G=0 / 000\end{array}$} & Cognition-based trust & \multirow[b]{2}{*}{$68 / 689$} \\
\hline & & Reason-based trust & \\
\hline \multirow{3}{*}{ Tax fairness } & \multirow{3}{*}{$\begin{array}{c}\text { KMO }=0 / 637 \\
\text { Chi-Square }=78 / 651 \\
\text { SIG }=0 / 000\end{array}$} & Procedural justice & \multirow{3}{*}{$53 / 743$} \\
\hline & & Distributive justice & \\
\hline & & Retributive justice & \\
\hline \multirow{3}{*}{ Tax morale } & \multirow{3}{*}{$\begin{array}{c}K M O=0 / 767 \\
\text { Chi-Square }=124 / 65 \\
\text { SIG }=0 / 000\end{array}$} & Moral obligation & \multirow{3}{*}{$61 / 213$} \\
\hline & & Tell the truth & \\
\hline & & Contributing to the society & \\
\hline \multirow{3}{*}{$\begin{array}{l}\text { Tax } \\
\text { compliance }\end{array}$} & \multirow{3}{*}{$\begin{array}{c}K M O=0 / 745 \\
\text { Chi-Square }=199 / 45 \\
\text { SIG }=0 / 000\end{array}$} & Filing compliance & \multirow{3}{*}{$56 / 364$} \\
\hline & & Reporting compliance & \\
\hline & & Payment compliance & \\
\hline
\end{tabular}

\section{Structural Equation Model Analysis}

Structural equation modeling (SEM) is defined as the analyzing of a latent variable and the causal modeling based on its outcome from the test of parameter estimation for the direct and the indirect relationship that exists between the endogenous, exogenous and mediating variables (Mustapha et al., 2015). In figure 1, the maximum likelihood (ML) method of estimation was used in order to maximize the obtainable value to predict the applicability of the data. To have a satisfactory fitness to data, normed Chi-square $(\chi 2 / \mathrm{df})$ of the model should be less than (3), normed fit index (NFI), comparative fit index (CFI), and Incremental Fit Index (IFI) more than (0.90), root mean squared residual (RMR) less than (0.09), and root mean squared error of approximation (RMSEA) less than (0.05). For the CFA model, $(\chi 2 / \mathrm{df})$ was (2.06), NFI, CFI, and IFI were (0.937), (0.946), and (0.917), RMR was (0.06) respectively, and RMSEA was (0.04). These statistics represents the goodness-of-fit to data for the CFA model.

To validate relationships between variables and to investigate the overall fitness of the proposed model, path analysis was used. To accept or reject the hypotheses, the standardized path coefficients and significant levels were used. It should be noted that the confidence level for all paths 
is assumed to be (0.95). Figure 2 shows the fitted path model revealing the intensity and the direction of relationship.

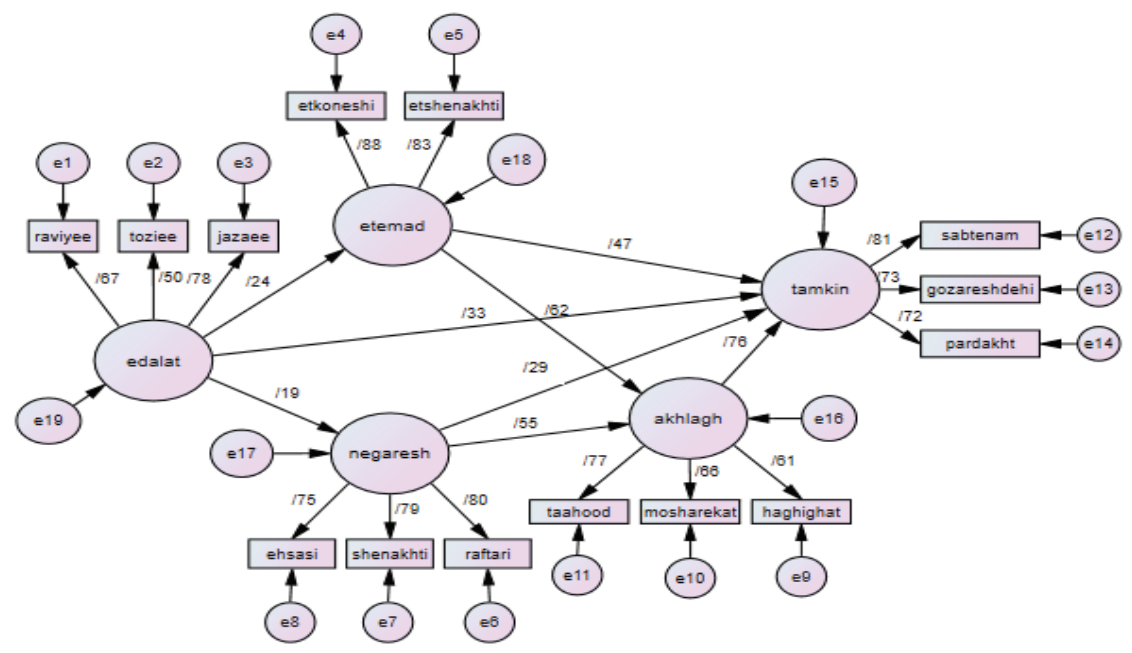

Figure 2: Structural Equation Model

\section{Hypothesis Testing with Path Analysis}

As previously mentioned, this study comprised of nine hypotheses. In order to test the hypotheses, the value of path coefficients and the respective level of significance were used (Table 3 ). A hypothesis is accepted if its significance level is lower than (0.05).

Table 3: Path Analysis Results

\begin{tabular}{llccc}
\hline \multicolumn{1}{c}{ Hypothesis } & $\begin{array}{c}\text { Path } \\
\text { coefficient }\end{array}$ & P-Value & Result \\
\hline $\boldsymbol{H}_{1}$ & Tax fairness $\rightarrow$ Taxpayers' attitude & $0 / 19$ & $0 / 000$ & Supported \\
\hline $\boldsymbol{H}_{2}$ & Tax fairness $\rightarrow$ Trust in authorities & $0 / 24$ & $0 / 005$ & Supported \\
\hline $\boldsymbol{H}_{3}$ & Tax fairness $\rightarrow$ Tax compliance & $0 / 33$ & $0 / 000$ & Supported \\
\hline $\boldsymbol{H}_{4}$ & Taxpayers' attitude $\rightarrow$ Tax morale & $0 / 55$ & $0 / 389$ & Not supported \\
\hline $\boldsymbol{H}_{5}$ & Taxpayers' attitude $\rightarrow$ Tax compliance & $0 / 29$ & $0 / 033$ & Supported \\
\hline $\boldsymbol{H}_{6}$ & Trust in authorities $\rightarrow$ Tax morale & $0 / 62$ & $0 / 000$ & Supported \\
\hline $\boldsymbol{H}_{7}$ & Trust in authorities $\rightarrow$ Tax compliance & $0 / 47$ & $0 / 000$ & Supported \\
\hline $\boldsymbol{H}_{8}$ & Tax morale $\rightarrow$ Tax compliance & $0 / 76$ & $0 / 000$ & Supported \\
\hline
\end{tabular}


As shown in Table 3, the majority of the hypothesized paths are significant, except the relationship between taxpayers' attitude and tax morale. Hypothesis testing showed that $H_{1}, H_{2}, H_{3}, H_{5}, H_{6}, H_{7}$ and $H_{8}$ are supported. $\mathrm{H}_{4}$ was not supported. Based on these results, the direct path from tax morale to tax compliance is the highest direct prediction capability with a standardized path coefficient of 0/76 and the direct path from tax fairness to tax compliance was the lowest (significant) prediction capability with standardized path coefficient of $0 / 19$.

\section{CONCLUSION AND RECOMMENDATION}

Undoubtedly, taxation is the most reliable source for financing government expenditure and has become one of the most important and highly debated topics in the accounting, economics and law literature. It is not clear why, in spite of the importance of tax revenue and greater enforcement mechanisms, non-tax compliance continues to exist. Regarding the widespread phenomenon of tax evasion, there has been a considerable shift in research emphasis and policy practices around the world from the analysis of enforcement to improving incorporation of trust-building measures that encourage voluntary cooperation. On the other hand, the main point which should be considered is that, in order to promote voluntary tax compliance, the executive and legal factors are usually taken into consideration and less attention is paid to social-psychological factors. So, our paper focused attention on the role and the effects of social-psychological factors on tax compliance. We identified these factors from the literature and many researchers who have studied the effects of one or some of these factors in their studies. We took them together in an integrated model and examined the relationship between them. The findings showed that tax fairness effect taxpayers' attitude, trust in authorities, tax morale and tax compliance. Consistent with the existing literature (e.g. Murphy, 2004), the analyses revealed that when more procedural fairness was perceived, more positive attitudes towards tax compliance emerged and trust in authorities became more and more which is consistent with results of the other research (e.g. Wenzel \& Thielmann, 2006; Job et al., 2007). Furthermore, if the tax burden is viewed as fair by majority of the of taxpayers, this will increase their tax morale thus resulting in a more transparent income declaration for tax purposes. These finally stimulates voluntary tax compliance (e.g. 
Levi \& Sacks, 2009). In addition, the results showed that as the taxpayers have more trust on the authorities, they do their role (filing compliance, reporting compliance and payment compliance) better. These results are in line with other researches (Mas'ud et al., 2014; Gobena \& Van Dijke, 2015) identifying trust as the main component for explaining voluntary tax compliance. In general, the positive effect of trust on honest tax reporting as reported in the literature was confirmed (Bergman, 2002; Torgler, 2003; Murphy, 2004; Torgler \& Schneider, 2005). And, also, various studies report that trust in the government and in governmental institutions positively influences tax morale which is a similar finding in this study too. Lastly, the findings showed the positive and strong effects of tax moral on tax compliance. In addition, in the light of the findings of this research, a number of implications were identified and we have some recommendations for tax managers and authorities. Table 4 shows the research recommendations.

Table 4: Research Recommendations

1 The findings demonstrated that in formulating strategies to enhance voluntary compliance, it is crucial for the relevant authorities to be aware of taxpayers' compliance behavior and they do their best to provide tax education services.

2 Use of strong executive guarantees, not enhancing the perception of retributive justice, while promotes tax compliance behaviors.

3 Trustworthy and honesty treatment of tax authorities can lead to trust of taxpayers to them in turn. In fact, there is a need for trust to be built between the citizens and the state in order to eliminate individuals' incentives of evading taxes. In order to facilitate this, transparency and accountability in the taxation system must be enforced and publicized.

4 The tax authorities should try to be fair in their decisions and give right information to the taxpayers during auditing.

5 Providing enough news and information about the use of tax collected in various media such as TV, radio, newspaper. It has a positive impact on the thought and attitude of taxpayers and will enhance the trust of the taxpayers. Perhaps this is one of the most important expectations of taxpayers from the government to understand the way of using tax collected by government.

6 As the tax officials do their job with more professionalism and dedication, the cognition-based trust will enhance and the tax compliance will happen.

7 Tax authorities should consult widely with taxpayers about how they might change things to make it easier for taxpayers to meet their obligations.

8 Enhancing the knowledge and skill of tax authorities for doing accurate and fair auditing which in turn enhance the taxpayers' trust and change their attitude. 


\section{CONTRIBUTION OF THE STUDY}

The study helps in understanding the concept of sustainable tax compliance and also highlights the social-psychological factors such as tax fairness, taxpayers' attitude, trust in authorities and tax morale, which influences tax compliance. For some reasons, it is imperative to know what factors are significant in influencing tax compliance. At first, today any government anywhere understand that they need sustainable recourse for their expenditures and financing their projects and nothing can replace tax. Second, no research has taken into consideration the factors influencing tax compliance in a holistic model. The study attempted to fulfill the research gap in the field of taxation as the area is still not widely covered. Finally, over the past decades it has become rather clear that the authoritarian method of enforcing tax compliance by threatening with coercive measures might be unproductive and most of the researches and studies examine the economic and structural factors affecting tax compliance While the psychological and intrinsic factors can be key elements influencing tax compliance. Actually, by knowing the social-psychological factors influencing it, proper attention can be given to these factors. The government and the Iranian National Tax Administration can concentrate and strengthen all these factors to promote sustainable tax collection.

\section{REFERENCES}

Abdul-Razak, A., \& Adafula, C. J. (2013). Evaluating taxpayers' attitude and its influence on tax compliance decisions in Tamale, Ghana. Journal of Accounting and Taxation, 5(3), 48-57.

Ajzen, I. (1991). The theory of planned behavior. Organizational Behavior and Human Decision Processes, 50(2), 179-211.

Alasfour, F., Samy, M., \& Bampton, R. (2016). The determinants of tax morale and tax compliance: Evidence from Jordan. Advances in Taxation, 23, 125-171.

Alm, J., Martinez-Vazquez, J., \& Schneider, F. (2004). "Sizing” the problem of the hard-to-tax. Contributions to Economic Analysis, 268, 11-75. 
Almasi, H., Ameli, A., \& Hajmohamadi, F. (2014). The study of taxpayer's perceptions of tax system's fairness and its effect on tax compliance behavior. Journal of Tax Research, 22(22), 221-249.

Bagozzi, R. P., \& Edwards, J. F. (1998). A general approach to construct validation in organizational psychology: Application to the measurement of work values. Organizational Research Methods, 1(1), 45-87.

Bajada, C. (2003). Business cycle properties of the legitimate and underground economy in Australia. Economic Record ,79, 397-411.

Bobek, D. D., Hageman, A. M., \& Kelliher, C. F. (2013). Analyzing the role of social norms in tax compliance behavior. Journal of Business Ethics, 115(3), 451-468.

Breckler, S. J., \& Wiggins, E. C. (1989). Affect versus evaluation in the structure of attitudes. Journal of Experimental Social Psychology, 25(3), 253-271.

Brown, R. E., \& Mazur, M. J. (2003). IRS's comprehensive approach to compliance. Paper presented at the National Tax Association Spring Symposium, Washington D. C.

Castro, L., \& Scartascini, C. (2015). Tax compliance and enforcement in the pampas evidence from a field experiment. Journal of Economic Behavior \& Organization, 116, 65-82.

Chan, C. W., Troutman, C. S., \& O'Bryan, D. (2000). An expanded model of taxpayer compliance: Empirical evidence from USA and Hong Kong. Journal of International Accounting Auditing and Taxation, 9(2), 83-103.

Chau, G., \& Leung, P. (2009). A critical review of Fischer tax compliance model: A research synthesis. Journal of Accounting and Taxation, 1(2), $34-40$.

Dell'Anno, R. (2009). Tax evasion, tax morale and policy maker's effectiveness. Journal of Socio-Economics, 38, 988-997. 
Feld, L., \& Frey, B. (2002). Trust breeds trust: How taxpayer are treated. Economics of Governance, 3, 87-99.

Frey, B. S. (2003). Deterrence and tax morale in the European Union. European Review, 11(3), 385-406.

Gobena, L. B., \& Van Dijke, M. (2015). Power, justice, and trust: A moderated mediation analysis of tax compliance among Ethiopian business owners. Journal of Economic Psychology, 52, 24-37.

Hair, J. F., Anderson, E. R., Tatham, L. R., \& Black, C. W. (1998). Multivariate data analysis (5th ed.). New Jersey, USA: Prentice-Hall.

Hammar, H., Jagers, S. C., \& Nordblom, K. (2009). Perceived tax evasion and the importance of trust. Journal of Socio-Economics, 38(2), $238-245$.

Horodnic, I. A. (2018). Tax morale and institutional theory: A systematic review. International Journal of Sociology and Social Policy, 38(9/10), 868-886.

Ibrahim, M., Musah, A., \& Abdul-Hanan, A. (2015). Beyond enforcement: What drives tax morale in Ghana. Humanomics, 31(4), 399-414.

Jayawardane, D., \& Low, K. (2016). Taxpayer attitude and tax compliance decision in Sri Lanka - How the taxpayers' attitudes influence tax compliance decision among individual taxpayers in Colombo City in Colombo District. International Journal of Arts and Commerce, 5(2), 124-135.

Jimenez, P., \& Iyer, G. S. (2016). Tax compliance in a social setting: The influence of social norms, trust in government, and perceived fairness on taxpayer compliance. Advances in Accounting, 34, 17-26.

Kastlunger, B., Lozza, E., Kirchler, E., \& Schabmann, A. (2013). Powerful authorities and trusting citizens: The slippery slope framework and tax compliance in Italy. Journal of Economic Psychology, 34, 36-45. 
Kim, S. (2008). Does political intention affect tax evasion? Journal of Policy Modeling, 30, 401-415.

Kirchler, E., Hoelzl, E., \& Wahl, I. (2008). Enforced versus voluntary compliance: The "Slippery Slope" framework. Journal of Economic Psychology, 29(2), 210255.

Kogler, C., Batrancea, L., Nichita, A., Pantya, J., Belianin, A., \& Kirchler, E. (2013). Trust and power as determinants of tax compliance: Testing the assumptions of the slippery slope framework in Austria, Hungary, Romania and Russia. Journal of Economic Psychology, 34, 169-180.

Leonardo, G., \& Martinez-Vazquez, J. (2016). Politicians, bureaucrats, and tax morale: What shapes tax compliance attitudes? (Working Paper No. 16-08). International Center for Public Policy, Andrew Young School of Policy Studies, Georgia State University.

Levi, M., \& Sacks, A. (2009). Legitimating beliefs: Sources and indicators. Regulation \& Governance, 3(4), 311-333.

Lin, C. P., \& Ding, C. G. (2006). Evaluating the group differences in gender during the formation of relationship quality and loyalty in ISP service. Journal of Organizational and End User Computing, 18(1), 38-62.

Loo, E. C., McKerchar, M., \& Hansford, A. (2007). The effect of the introduction of self-assessment on tax knowledge of individual taxpayers in Malaysia: Survey findings. Paper presented at the Accounting Studies International Conference, Kuala Lumpur, Malaysia, 30-31 October.

McCoon, M. (2011). Tax compliance in Latin America: A cross country analysis. Journal of Finance and Accountancy, 7(1), 1-16.

Merima, A., Odd-Helge, F., \& Ingrid, H. S. (2013). To pay or not to pay? Citizens' attitudes towards taxation in Kenya, Tanzania, Uganda and South Africa. World Development, 64, 828-842.

Murphy, K. (2003). An examination of taxpayers' attitudes towards the Australian tax system: Findings from a survey of tax scheme investors. Australian Tax Forum, 18, 209-242. 
Musimenta, D., Nkundabanyanga, K. S., Muhwezi, M., Akankunda, B., \& Nalukenge, I. (2017). Tax compliance of small and medium enterprises: A developing country perspective. Journal of Financial Regulation and Compliance, 25(2), 1-19.

Mustapha, B., Normala, S., \& Obid, S. (2015). Tax service quality: The mediating effect of perceived ease of use of the online tax system. Procedia - Social and Behavioral Sciences, 172, 2 - 9.

Nawawi, A., \& Salin, A. S. A. P. (2018). Capital statement analysis as a tool to detect tax evasion. International Journal of Law and Management, 60(5), 1163-1178.

Ndekwa, G. A. (2014). Factors for improving tax compliance among small and medium enterprises in Tanzania. The International Journal of Business and Management, 2(10), 285-290.

Night, S., \& Bananuka, J. (2018). The mediating role of adoption of an electronic tax system in the relationship between attitude towards electronic tax system and tax compliance. Journal of Economics, Finance and Administrative Science.

Nkundabanyanga, S. K., Mvura, P., Nyamuyonjo, D., Opiso, J., \& Nakabuye, Z. (2017). Tax compliance in a developing country: Understanding taxpayers' compliance decision by their perceptions. Journal of Economic Studies, 44(6), 931-957.

Nkwe, N. (2013). Tax payers' attitude and compliance behavior among small medium enterprises (SMEs) in Botswana. Business and Management Horizons, 1(1), 113-137.

Onu, D. (2016). Measuring tax compliance attitudes: What surveys can tell us about tax compliance behavior. Advances in Taxation, 23, 173-190.

Osundina, C. K., \& Olanrewaju, G. O. (2013). Welfare effects of taxation on the Nigerian country. International Journal of Humanities and Social Science Invention, 2(8), 76-82. 
Rousseau, D. M., Sitkin, S. B., Burt, R. S., \& Camerer, C. (1998). Not so different after all: A cross-discipline view of trust. Journal of Management, 39(7), 1891-1923.

Sá, C., Martins A., \& Gomes, C. (2014). Tax morale, occupation and income level: An analysis of Portuguese taxpayers. Journal of Economics, Business and Management, 2(2), 112-116.

Sameti, M., Amiri, H., \& Heydari, Z. (2015). The effects of tax morale on tax compliance (Case study: The Isfahan city). Quarterly Journal of Economic Research and Policies, 23(75), 231-262.

Schneider, F. (2000). The value added of underground activities: Size and measurement of the shadow economies and shadow economy labour force all over the world. (International Monetary Fund Discussion Paper WP/00/26).

Schneider, F., \& Enste, D. (2000). Shadow economies: Size, causes, and consequences. Journal of Economic Literature, 38, 77-114.

Soleimani, M., Danaei, H., Jowkar, A., \& Parhizgar, M. M. (2017). Factors affecting social commerce and exploring the mediating role of perceived risk (Case study: Social media users in Isfahan). Iranian Journal of Management Studies, 10(1), 41-60.

Solomon, M., Bamossy, G., Askegaard, S., \& Hogg, M. (2006). Consumer behavior: A European perspective. London: Prentice Hall.

Tax Justice Network (2011). The cost of tax abuse: A brief paper on the cost of tax evasion worldwide. Retrieved from http://www.taxjustice. net/cms/front_content.php?idcat $=2$

Terkper, S. (2003). Managing small and medium-size taxpayers in developing economies. Tax Notes International 13 January 2003.

Torgler, B. (2004). Tax morale in Asian countries. Journal of Asian Economics, 15, 237-266. 
Torgler, B. (2005). Tax morale and direct democracy. European Journal of Political Economy, 21(2), 525-531.

Torgler, B. (2007). Tax compliance and tax morale: A theoretical and empirical analysis. Northampton, MA: Edward Elgar Publishing, Inc.

Torgler, B., \& Schneider, F. (2005). Attitudes towards paying taxes in Austria: An empirical analysis. Empirica, 32, 231-250.

Torgler, B., \& Valev, N. (2010). Gender and public attitudes toward corruption and tax evasion. Contemporary Economic Policy, 28(4), 554-568.

Trivedi, V. U., Shehata, M., \& Mestelman, S. (2005). Attitudes, incentives and tax compliance. Canadian Tax Journal, 52(1), 29-61.

Van Dijke, M., De Cremer, D., \& Mayer, D. M. (2010). The role of authority power in explaining procedural fairness effects. Journal of Applied Psychology, 95(3), 488-502.

Wahl, I., Kastlunger, B., \& Kirchler, E. (2010). Trust in authorities and power to enforce tax compliance: An empirical analysis of the slippery slope framework. Law \& Policy, 32(4), 383-406.

Yeniçeri, H. (2004). Beyan esasına dayanan vergilerde vergi kayıp ve kaçaklarının psikolojik nedenlerinin tespitine yönelik bir araştırma. 19. Turkey Public Finance Symposium Book, Antalya.

Young, A., Danny, C., \& Daniel, H. (2013). A study of the impact of culture on tax compliance in China. International Tax Journal, 39, 33-47. 